„FOLIA BIBLIOLOGICA” (2019), VOL. LXI

DOI: $10.17951 / \mathrm{fb} .2019 .61 .63-83$

\author{
Joanna Zętar \\ Wydział Politologii i Dziennikarstwa \\ Uniwersytet Marii Curie-Skłodowskiej w Lublinie \\ Ośrodek „Brama Grodzka - Teatr NN” w Lublinie \\ https://orcid.org/0000-0002-0377-6272
}

\title{
WIELKA KSIĘGA MIASTA. FOTOGRAFIE LUBELSKIEJ \\ DZIELNICY ŻYDOWSKIEJ W ZBIORACH OŚRODKA „BRAMA GRODZKA - TEATR NN”
}

\begin{abstract}
Streszczenie: Artykuł przedstawia historię, sposób tworzenia oraz zasób repozytorium cyfrowego Biblioteki Multimedialnej Teatru NN. Analizie poddano zawartość zbiorów ikonograficznych tworzonych przez Ośrodek „Brama Grodzka - Teatr NN”, w szczególności źródła dotyczące historii lubelskiej społeczności żydowskiej. Bogata dokumentacja fotograficzna dzielnicy żydowskiej powstała w okresie dwudziestolecia międzywojennego za sprawą fotoamatorów i zawodowych fotografów: Jana Bułhaka, Józefa Czechowicza, Edwarda Hartwiga, Altera Kacyzne, Stefana Kiełszni, Stanisława Magierskiego, Henryka Poddębskiego i Wiktora Ziółkowskiego. Rozważania ukazują znaczenie fotografii w dokumentowaniu historii oraz zachowaniu pamięci o ludziach i miejscach.
\end{abstract}

Słowa kluczowe: Lublin, dzielnica żydowska, Podzamcze, fotografia, ośrodek „Brama Grodzka Teatr NN", ikonografia, biblioteka cyfrowa

\section{The Great Book of the City. Photographs from Jewish disctrict in Lublin from the Ośrodek „Brama Grodzka - Teatr NN” Archive}

\begin{abstract}
The article refers the history of digital repository of Bibliotka Multimedialna Teatru NN. The text analyzes the content of iconographic collections created by the "Grodzka Gate NN Theater" Center, specifically focused on visual sources to the history of the Lublin Jewish community. The aim of the article is to organize the collected material from the perspective of photography as a historical source. The research problem is the analysis of material supplementing the research on reconstruction of the city's history.
\end{abstract}

Keywords: Lublin, jewish district, Podzamcze, photography, „Brama Grodzka - Teatr NN” Centre, iconography, digital library 
„Staliśmy się zapisywaczami tego morza opowieści, współtwórcami Wielkiej Opowieści o przedwojennym Lublinie. [...] Powstaje księga, która jest rodzajem zielnika z życiorysami, wspomnieniami, rodzinnymi fotografiami, fotografiami domów, ludzi, ulic, mieszkań, poetyckimi opisami miasta, legendami. Rodzi się opowieść o życiu mieszkańców, opowieść o mieście, którego już nie ma” - pisał o pracy z pamięcią, podjętej na początku działalności Ośrodka „Brama Grodzka Teatr NN" jego twórca i założyciel Tomasz Pietrasiewicz. Początek budowania tej opowieści miał miejsce we wczesnych latach 90. XX wieku, kiedy w Bramie Grodzkiej zrodził się pomysł stworzenia instytucji gromadzącej informacje o żydowskim Lublinie. Idea ta powstała, ponieważ do wybuchu II wojny światowej bezpośrednio za Bramą Grodzką znajdowała się dzielnica w większości zamieszkana przez Żydów, a brama prowadząca do tej części miasta potocznie była zwana Bramą Żydowską.

\section{Wielka Księga Miasta}

W roku 1997 z inicjatywy powołanego już formalnie do życia jako samorządowej instytucji kultury Ośrodka „Brama Grodzka - Teatr NN” w „Gazecie Wyborczej w Lublinie” opublikowano apel skierowany do lublinian o dostarczanie przedwojennych zdjęć w celu zorganizowania wystawy dokumentalnej. Akcja społeczna nosząca tytuł „Wielka Księga Miasta” spotkała się z ogromnym zainteresowaniem ze strony mieszkańców². Zebrane fotografie posłużyły do stworzenia dwóch ekspozycji: „Wielka Księga Miasta. Lublin w fotografii do 1939 roku” otwartej w maju 1998 roku oraz „Portret Miejsca. Lubelski Zespół Staromiejski do 1939 roku”, której wernisaż miał miejsce w 1999 roku$^{3}$. Materiały pozyskane podczas akcji stały się podstawą stworzenia Archiwum Fotografii, którego początek datuje się na 1997 rok. Początki zasobu to przede wszystkim zbiory prywatne, między innymi Symchy Wajsa, Jerzego Kiełszni, Romana Krawczyńskiego, rodziny Magierskich. Po zakończeniu akcji „Wielka Księga Miasta” kwerendę rozszerzono na zbiory instytucji statutowo zajmujących się gromadzeniem i przechowywaniem dokumentów archiwalnych: bibliotek, muzeów i archiwów, zarówno w kraju, jak i za granicą. Pracownicy Ośrodka zaczęli pozyskiwać materiały z zasobów lubelskich instytucji - Wojewódzkiej Biblioteki Publicznej im. Hieronima Łopacińskiego, Państwowej Służby Ochrony Zabytków

${ }^{1}$ Przypadek zamierzony. Dlaczego właśnie Krawiecka 41, z Tomaszem Pietrasiewiczem rozmawia Marcin Skrzypek, „Scriptores” 2003, nr 28, s. 197.

2 Więcej o akcji „Wielka Księga Miasta”: M. Bielecka-Hołda, Wielka Księga Miasta, „Scriptores”: Poza kadrem. Fotografia w Lublinie w latach 1839-1939, 2019, nr 48, s. 323-334.

3 Więcej informacji o wystawach w Kalendarium Ośrodka „Brama Grodzka - Teatr NN”: [online] www.kalendarium.teatrnn.pl [dostęp: 15.01.2020]. 
w Lublinie (obecnie Lubelski Wojewódzki Konserwator Zabytków), archiwum Miejskiego Przedsiębiorstwa Wodociągów i Kanalizacji, Wydziału Architektury i Urbanistyki Urzędu Miasta, a także spoza Lublina - Instytutu Sztuki PAN, Ghetto Fighters' House, YIVO Institute for Jewish Research. Archiwum Fotografii z czasem zostało przekształcone w Pracownię Ikonografii Ośrodka „Brama Grodzka - Teatr NN", która od 2005 roku zajmuje się zbieraniem, opracowywaniem i udostępnianiem materiałów wizualnych Lublina i Lubelszczyzny. Obecnie (styczeń 2020 roku) zbiory Pracowni stanowią przede wszystkim cyfrowe kopie zdjęć, również przekazane $\mathrm{w}$ formie darowizny lub depozytu odbitki na papierze, negatywy szklane i celuloidowe, diapozytywy oraz skany dokumentów, planów i map, a także cyfrowe reprodukcje dzieł sztuki

Zasób Pracowni Ikonografii Ośrodka „Brama Grodzka - Teatr NN” jest przykładem - jednego z pierwszych w Polsce - archiwum społecznego, od początku gromadzącego przede wszystkim cyfrowe materiały archiwalne ${ }^{5}$. W większości przypadków wypożyczane na czas digitalizacji fotografie są zwracane właścicielom. Pliki cyfrowe tworzone zgodnie z obowiązującymi standardami archiwizacji są następnie archiwizowane, opracowywane i opisywane. Istotnym elementem działań podejmowanych przez Pracownię jest jak najszersze udostępnianie zbiorów. Początkowe prezentacje zasobów w ramach wspomnianych wystaw czasowych, a następnie wystawy stałej funkcjonującej od 1999 roku pod tytułem „Portret Miejsca”, przekształconej następnie w 2009 roku w ekspozycję „Pamięć Miejsca”, okazały się niewystarczające, głównie ze względu na dużą liczbę zgromadzonych materiałów i małą przestrzeń wystawienniczą. Rozwiązaniem tego problemu okazał się internet.

Początkowo materiał był udostępniany w wortalu „Wirtualna Biblioteka Lublina i Regionu Lubelskiego", który został uruchomiony w 2003 roku. Jego celem było zaprezentowanie multimedialnych opowieści o Lublinie tworzonych na podstawie zgromadzonych i udostępnionych online materiałów dokumentalnych. Wortal w 2009 roku został przekształcony w Bibliotekę Multimedialną Teatru NN (biblioteka.teatrnn.pl), której działanie zostało oparte na systemie dLibra służącym do tworzenia bibliotek cyfrowych. Wart podkreślenia jest fakt, że biblioteka cyfrowa tworzona przez Ośrodek w oparciu o dLibrę była pierwszym w kraju wdrożeniem tego rozwiązania technologicznego, w którym na taką skalę opublikowano obok materiałów tekstowych materiały ikonograficzne w formie zdjęć oraz multimedialne

${ }^{4}$ Więcej o historii i zasobach archiwum Pracowni Ikonografii w: M. Fedorowicz, Fotografie Lublina do 1939 roku w zbiorach Pracowni Ikonografii Ośrodka „Brama Grodzka - Teatr NN”, „Scriptores”: Poza kadrem. Fotografia w Lublinie w latach 1839-1939, 2019, nr 48, s. 335-364.

${ }^{5}$ Obecnie na jego zasób oprócz Archiwum Pracowni Ikonografii składa się Archiwum Pracowni Historii Mówionej, która gromadzi audiowizualne relacje świadków historii. 
w postaci plików audio i video. Biblioteka od 2010 roku jest członkiem Federacji Bibliotek Cyfrowych (fbc.pionier.net.pl), a od 2016 r. Europeany (www.europeana. eu). Jest również jednym z podmiotów tworzących regionalny, międzybiblioteczny projekt Lubelskiej Biblioteki Wirtualnej (lbw.lublin.eu) ${ }^{6}$. Zasoby Pracowni Ikonografii są obecnie ważną częścią repozytorium cyfrowego Biblioteki Multimedialnej Teatru NN. W repozytorium opublikowano 105870 rekordów (dane z 20.01.2020 r.), z czego 52312 stanowią publikacje zawierające materiały ikonograficzne, w tym fotografie.

Dotychczasowe działania prowadzone w Ośrodku „Brama Grodzka - Teatr NN” pozwoliły na zgromadzenie w archiwum Pracowni Ikonografii informacji przede wszystkim na temat przedwojennego Lublina. Najważniejszym obszarem zainteresowań jest nieistniejąca dzielnica żydowska, której stale opisywana i odkrywana historia jest „kodem genetycznym” Ośrodka. Fotografie są elementem opowieści Bramy Grodzkiej. W podejmowanych działaniach nie chodzi wyłącznie o proces digitalizacji, ale o włączanie go w szersze działania, mające na celu popularyzację wiedzy o dziedzictwie za pomocą multimedialnych narracji. Z punktu widzenia tworzenia opowieści ważne było połączenie w 2006 roku repozytorium z serwisem „Lublin. Pamięć Miejsca”, przekształconym w 2009 roku w „Leksykon. Lublin”, który jest multimedialną encyklopedią w przystępny sposób przekazującą informacje o historii Lublina i dziedzictwie kulturowym miasta.

Materiały fotograficzne są też ważnymi elementami projektów realizowanych w Ośrodku. Jednym z nich jest projekt „Archiwum Miasta”. Polega on na mapowaniu w topografii Lublina miejsc ważnych dla społeczności żydowskiej. Materiały archiwalne, takie jak zdjęcia, dokumenty prywatne, wspomnienia i relacje rozproszone $\mathrm{w}$ wielu miejscach przechowywania - w archiwach, bibliotekach, zbiorach prywatnych - są porządkowane i systemowo katalogowane, a następnie kompilowane z indywidualnymi historiami świadków i innymi dokumentami gromadzonymi w Ośrodku. Tworzą one „księgę pamięci”, rozpisaną niczym księga adresowa, ponieważ historie są porządkowane według adresów. Nie jest to jedyny projekt o charakterze archiwalnym, jaki w ostatnim czasie podął Ośrodek. Podobny charakter ma projekt „Lublin. 43 tysiące” również wykorzystujący zasoby fotograficzne. Ma on na celu dotarcie do informacji o każdym z żydowskich mieszkańców przedwojennego Lublina (stąd liczba czterdzieści trzy tysiące w nazwie projektu), nawet jeżeli jest to informacja zdawkowa, oparta na imieniu i nazwisku, jednym zdjęciu lub jego

6 Więcej o działaniach Ośrodka „Brama Grodzka - Teatr NN” w obszarze digitalizacji i nowych mediów w: R. Bomba, Brama 2.0. Animacja kultury cyfrowej w działaniach Ośrodka „Brama Grodzka - Teatr NN”, „Konteksty. Polska Sztuka Ludowa”: Misterium Bramy. Antropologia Pamięci, 2017, R. LXXI, nr 3 (318), s. 141-148. 
fragmencie albo zawarta w kilku na pozór mało konkretnych zdaniach lub słowach. Projekt jest przykładem procesu pracy z pamięcią polegającym na przeszukiwaniu materiałów archiwalnych związanych z życiem i Zagładą wszystkich członków lubelskiej społeczności żydowskiej

Oba projekty wpisują się w zjawisko gorączki archiwów, o którym Jacques Derrida pisał jako o gorączkowym poszukiwaniu źródeł oraz wykorzystywaniu archiwizacyjnego potencjału mediów cyfrowych w celu zgromadzenia i uporządkowania jak największej ilości informacji.

\section{Historia miejsca}

Osadnictwo żydowskie rozpoczęło się w Lublinie na przełomie XV i XVI wieku wzdłuż istniejącego wówczas traktu komunikacyjnego łączącego Kraków i Wilno. Z czasem dzielnica żydowska rozlokowała się wokół Wzgórza Zamkowego, dlatego zyskała nazwę Podzamcza. Stosunkowo wcześnie miejsce to zyskało wysoką rangę wśród polskiej społeczności żydowskiej, o czym świadczą między innymi określenia Lublina jako Jerozolimy Królestwa Polskiego albo żydowskiego Oksfordu. Od 1547 roku rozwijało się w Lublinie hebrajskie drukarstwo, od 1580 roku obradował tu Sejm Czterech Ziem, w latach 90. XVIII wieku założył swój dwór Jakub Icchak Horowitz zwany Widzącym z Lublina, a w 1930 roku została otwarta największa w tej części Europy uczelnia talmudyczna - Jeszywas Chachmej Lublin. Przed 1939 rokiem żydowska społeczność Lublina stanowiła 1/3 populacji miasta - Drugi Powszechny Spis Ludności przeprowadzony w 1931 roku wykazał, że z 112285 osób mieszkających w Lublinie 38937 deklarowało wyznanie mojżeszowe $^{8}$. Podczas II wojny światowej nastąpiła Zagłada tego miasta. Dnia 24 marca 1941 roku okupanci utworzyli getto, na którego teren przymusowo przesiedlono ponad 34 tysiące osób. W nocy z 16 na 17 marca 1942 roku rozpoczęła się likwidacja getta, która zapoczątkowała akcję „Reinhardt” w Generalnym Gubernatorstwie.

7 Więcej o projektach Ośrodka „Brama Grodzka - Teatr NN” związanych z pamięcią: T. Pietrasiewicz, Teatr Pamięci Teatru NN, Lublin 2017; Teatr Pamięci Teatru NN. Flesze, red. P. Próchniak, Lublin 2018. Więcej o projektach o charakterze archiwalnym: P. Próchniak, Brama jako archiwum. Działania archiwizacyjne Ośrodka „Brama Grodzka - Teatr NN” w Lublinie, „Kultura i Społeczeństwo": Społeczne w archiwach, 2019, t. LXIII, nr 1, s. 113-123.

8 A. Jakubowski, U. Bronisz, E. Łoś, Historia Lublina w liczbach, Lublin 2017, s. 96. Więcej o historii lubelskich Żydów m.in.: M. Bałaban, Żydowskie miasto w Lublinie, tłum. J. Doktór, Lublin 2012 oraz Żydzi w Lublinie. Materiały do dziejów społeczności żydowskiej Lublina, red. T. Radzik, Lublin 1995; Żydzi lubelscy. Materiały z sesji poświęconej Żydom lubelskim, red. W. Hawryluk, G. Linkowski, Lublin 1996; R. Kuwałek, W. Wysok, Lublin. Jerozolima Królestwa Polskiego, Lublin 2001; Księga pamięci żydowskiego Lublina, wybór, oprac. i wstęp A. Kopciowski, Lublin 2011. 
Do 14 kwietnia 1942 roku około 28 tysięcy mieszkańców getta deportowano do obozu zagłady w Bełżcu. Niedługo po wysiedleniu mieszkańców Podzamcza w maju 1942 roku rozpoczęto pierwsze rozbiórki budynków z terenu dzielnicy żydowskiej. Pozostałych przy życiu umieszczono we wtórnym getcie na Majdanie Tatarskim, a po jego likwidacji 9 listopada 1942 roku około 3 tysiące Żydów trafiło do obozu na Majdanku, gdzie większość została zamordowana, m.in. w ramach akcji Erntefest, która miała miejsce 3 i 4 listopada 1943 roku.

Do II wojny światowej dzielnica żydowska na Podzamczu obejmowała obszar od ulicy Lubartowskiej aż za Wzgórze Zamkowe oraz wzdłuż ulicy Kowalskiej i Krawieckiej aż do ulicy Unickiej i tzw. rogatki lubartowskiej. Analizując topografię miasta, warto dodać, że ludność żydowska do 1939 roku nie zamieszkiwała wyłącznie na terenie Podzamcza, ale również na terenie Starego Miasta, na Kalinowszczyźnie, Wieniawie i Piaskach, gdzie stanowiła znaczny odsetek mieszkańców.

Dziś teren dawnej żydowskiej dzielnicy na Podzamczu jest miejscem, które dla wielu lublinian nie niesie za sobą żadnych znaczeń. Pustka jest konsekwencją wydarzeń, jakie miały miejsce podczas II wojny światowej i bezpośrednio po niej. Nastąpiła wtedy całkowita zmiana przestrzeni urbanistycznej, ponieważ w związku z obchodzonymi w 1954 roku ogólnopolskimi obchodami dziesięciolecia PKWN wybudowano plac Zebrań Ludowych (obecnie plac Zamkowy), który na nowo sfunkcjonalizował tę część miasta9 . Uporządkowanie miejsca spowodowało zniszczenie resztek elementów obszaru dzielnicy żydowskiej, rozpoczynając proces wymazywania pamięci o lubelskich Żydach z przestrzeni publicznej. Coraz trudniej, przemierzając tę część miasta, wyobrazić sobie, jak wyglądały miejsca dzielnicy na Podzamczu: ulica Szeroka, plac Krawiecki, synagoga Maharszala, partery domów mieszczące sklepy lub warsztaty rzemieślnicze, szyldy w języku jidysz, jak wyglądały zaprzęgi konne, gdzie najczęściej można było spotkać sprzedawców stojących przed wejściem do swoich sklepów i kobiety sprzedające bajgle, jak wyglądały bawiące się nieopodal studni i rynsztoków dzieci, a jak uczniowie chederów.

\section{Fotografie lubelskiej dzielnicy żydowskiej}

Źródłem wiedzy o krajobrazie, miejscach, architekturze i wizerunkach ludzi żyjących na Podzamczu są przekazy ikonograficzne, w szczególności fotografie. Ze względu na dużą wartość dokumentalną są podstawą do poznawania i pogłębiania

9 Więcej o przekształceniach urbanistycznych na obszarze Podzamcza: J. Zętar, Jak budowano plac Zamkowy..., „Gazeta Wyborcza. Magazyn Lubelski” 18.08.2017, s. 6-7; eadem, Szeroka - opowieść o ulicy, której nie ma, „Gazeta Wyborcza. Magazyn Lubelski” 25.08.2017, s. 8-9. 
wiedzy dotyczącej topografii tego fragmentu miasta. W chwili obecnej największą cyfrową kolekcję zdjęć dokumentujących lubelską dzielnicę żydowską funkcjonującą do II wojny światowej na Podzamczu w Lublinie posiada Ośrodek „Brama Grodzka - Teatr NN".

Fotografia lubelska ma długą i bogatą tradycję. Wynalazek Louisa Daguerre’a opatentowany w 1839 roku trafił nad Bystrzycę w II połowie XIX wieku do atelier fotograficznych zajmujących się głównie fotografią portretową. Prekursorką lubelskiej fotografii miejskiej była Wanda Chicińska (1850-1929 lub 1938), która w 1874 roku wydała składający się z dwudziestu zdjęć Album lubelskie. Niestety brakuje kompletnego materiału źródłowego pozwalającego na analizę ikonograficzną jego zawartości, dlatego trudno stwierdzić, czy pośród zdjęć znajdowały się ujęcia prezentujące Podzamcze. Fotografie powstałe w II połowie XIX i w I dekadzie XX wieku, m.in. w zakładach Wandy Chicińskiej, Wiktorii Sierocińskiej (około 1850 - po 1914), czy Stanisława Zawadzkiego (1863-1943), były wykorzystywane do produkcji pocztówek wydawanych przez lubelskich księgarzy i wydawców, m.in. Andrzeja Semadeniego, Władysława i Wiktora Kiesewetterów ${ }^{10}$. Są one podstawą opisu ówczesnego wyglądu miasta. Zdjęcia ukazują atrakcyjne i najbardziej reprezentacyjne budowle z obrębu Śródmieścia: Krakowskie Przedmieście, plac Litewski, kościoły i budynki użyteczności publicznej oraz z terenu Starego Miasta: Bramę Krakowską, Rynek i kamieniczki staromiejskie, co dowodzi wybiórczego potraktowania dokumentowanych miejsc. W niewielu przypadkach znajdujemy na nich widoki Podzamcza. Obszar ten ukazują widoki ogólne wykonywane z placu po Farze w stronę Wzgórza Zamkowego, ewentualnie wizerunki fragmentów Podzamcza znajdujące się bezpośrednio za Bramą Grodzką. Nie istnieją wykonane w tym czasie zdjęcia ulicy Jatecznej, Krawieckiej ani widoki zamieszkanych również przez Żydów przedmieść Kalinowszczyzna, Wieniawa czy Piaski. Pod względem kompozycyjnym fotografie są przede wszystkim panoramami lub ogólnymi ujęciami widoków ulic. W zasobach Pracowni Ikonografii Ośrodka „Brama Grodzka - Teatr NN" materiał tego rodzaju to cyfrowe kopie pocztówek pochodzących z prywatnej kolekcji pozyskanej od Zbigniewa Lemiecha.

Dokumentowanie dzielnicy żydowskiej rozpoczęło się w Lublinie na przełomie XIX i XX wieku. W powstałej około 1899 roku serii dwudziestu czterech fotografii autorstwa Zofii Grzybowskiej (1869 - po 1901) prawdopodobnie po raz pierwszy pojawia się widok dzielnicy żydowskiej. Na fotografii zatytułowanej „Były Zamek Królewski” widoczna jest bryła budowli na Wzgórzu Zamkowym oraz otaczające

10 J. Lipniewski, Widokówki lubelskie - historia i znaczenie dla ikonografii miasta (1896-1939), [w:] Ikonografia dawnego Lublina, red. Z. Nestorowicz, Lublin 1999, s. 88-119. 
je Podzamcze. Fotografie Grzybowskiej zostały opublikowane w warszawskim tygodniku „Świat”, a następnie w Pamiętniku lubelskim na rok 1904.

Przełomowym momentem w dokumentowaniu dzielnicy żydowskiej były fotografie wykonane około 1900 roku przez Wiktorię Sierocińską. Trzy połączone zdjęcia tworzące panoramę miasta od strony północnej ukazują dzielnicę żydowską z wyróżniającą się sylwetą synagogi oraz zabudowaniami ulicy Jatecznej i Szerokiej. Panorama wykonana przez Sierocińską po raz pierwszy została zaprezentowana na Wystawie Przemysłowo-Rolniczej, która odbyła się w Lublinie w 1901 roku, a później była rozpowszechniana jako widokówka-składanka ${ }^{11}$.

Najwięcej materiałów do ikonografii dzielnicy żydowskiej powstało w okresie dwudziestolecia międzywojennego za sprawą fotoamatorów i zawodowych fotografów: Jana Bułhaka, Józefa Czechowicza, Edwarda Hartwiga, Altera Kacyzne, Stefana Kiełszni, Stanisława Magierskiego, Henryka Poddębskiego i Wiktora Ziółkowskiego. Okres ten obfituje w autorskie kolekcje fotograficzne, m.in dzięki dynamicznie rozwijającej się technice fotografii, powiększeniu się liczby posiadaczy aparatów fotograficznych, a także za sprawą zinstytucjonalizowania się w Lublinie fotograficznego ruchu amatorskiego w Lubelskie Towarzystwo Fotograficzne.

Unikalnym zbiorem dokumentującym Lublin i dzielnicę na Podzamczu jest kolekcja zdjęć autorstwa Stefana Kiełszni (1911-1987) - pracownika Księgarni św. Wojciecha, fotoamatora, członka Lubelskiego Towarzystwa Fotograficznego i właściciela największej w Lublinie prywatnej biblioteki fotograficznej. W roku 1934 prawdopodobnie na zlecenie Magistratu Kiełsznia aparatem marki Rolleiflex wykonał około 600 zdjęć. Ze zbioru, który uległ rozproszeniu po II wojnie światowej, do dziś zachowało się 120 fotografii, na których oglądamy między innymi ulice Podzamcza: Kowalską, Szeroką, Krawiecką, Zamkową, Zamek Lubelski od strony ulicy Podwale, podwórka na Podzamczu, Bramę zwaną Zasraną. Fotograf w swoich kadrach zatrzymał głównie architekturę, ale także wizerunki typowych postaci - mieszkańców Lublina przemierzających w ciągu dnia ulice. Kolekcja jest bezcennym dokumentem, podstawą analiz i materiałem do odtwarzania wyglądu żydowskiej dzielnicy ${ }^{12}$. Oryginały fotografii znajdują się w zbiorach syna artysty Jerzego Kiełszni. Całość kolekcji jest dostępna w zbiorach Biblioteki Multimedialnej Teatru NN.

11 Więcej o początkach lubelskiej fotografii: „Scriptores”: Poza kadrem. Fotografia w Lublinie w latach 1839-1939, 2019, nr 48.

12 Więcej o fotografiach Stefana Kiełszni: B. Odnous, Fotograf zaginionego miasta, „Karta” 2000, nr 31, s. 10-15; H. Gawarecki, Dawny Lublin na fotografiach Stefana Kiełszni, Lublin 1975; D. Majuk, A. Wiśniewska, K. Dworniczak, Kiełsznia Stefan (1911-1987), „Scriptores”: Poza kadrem. Fotografia $w$ Lublinie w latach 1839-1939, 2019, nr 48, s. 162-173; Ulica Nowa 3. Stefan Kiesznia. Historyczne zdjęcia ulic żydowskiej dzielnicy w Lublinie, Lipsk 2011. 
Bardziej znany jako poeta, mniej jako fotograf Józef Czechowicz (1903-1939) zimą lub wczesną wiosną 1933 lub 1934 roku wykonał pięćdziesiąt sześć widoków Lublina, które powstały w ścisłym związku z opublikowanym w 1934 roku tomem poetyckim Stare kamienie i przygotowywanym Poematem o mieście Lublinie. Ukazują miejsca charakterystyczne dla pejzażu miasta, a także ulice i zaułki żydowskiej dzielnicy: Bramę Grodzką (zarówno od strony Starego Miasta, jak i dzielnicy żydowskiej), ulicę Krawiecką i plac Krawiecki, widok na ulicę Zamkową, widok na Podzamcze z placu po Farze, rzekę Czechówkę, Bramę Zasraną, a także obszar Kalinowszczyzny i Wieniawy. Fotografie znane z wykonanych pod koniec lat 60 . XX wieku negatywów są przechowywane w Muzeum Lubelskim, w oddziale poświęconym twórczości poety. Ponadto w prywatnej kolekcji Marii Lizut-Skwarek znajduje się trzynaście zdjęć sygnowanych nazwiskiem Czechowicza, datowanych na początek lat 20. XX wieku. Są pośród nich dwa zdjęcia pokazujące ogólne widoki Podzamcza ${ }^{13}$. Ośrodek digitalizował materiały z muzeum ze współczesnych odbitek, a z prywatnych zbiorów z albumu rodzinnego. Obie kolekcje są dostępne w zbiorach Biblioteki Multimedialnej Teatru NN.

Wiele zdjęć Lublina z II połowy lat 30 . XX wieku, ukazujących motywy z Podzamcza, ale także z terenu przedmieścia Wieniawa wykonał Stanisław Magierski (1904-1957) - farmaceuta, muzyk, malarz, fotograf, współzałożyciel Lubelskiego Towarzystwa Fotograficznego, właściciel sklepu z materiałami fotograficznymi, a także filmowiec, który w 1937 roku nakręcił siedmiominutowy film o Lublinie ${ }^{14}$. Spośród stu czterech skanów zdjęć pozostających w dyspozycji Ośrodka „Brama Grodzka - Teatr NN” kilkanaście przedstawia budynki przy ulicach Grodzkiej, Krawieckiej, Basztowej, Jatecznej, Podzamcze, Zamkowej, ponadto Bramę Zasraną oraz panoramę dzielnicy żydowskiej ze Wzgórza Czwartek. Skany fotografii zostały pozyskane od syna Stanisława Magierskiego - Jana, w którego rękach znajduje się cała spuścizna artysty. Materiały są dostępne w zbiorach Biblioteki Multimedialnej Teatru NN.

W tym samym czasie co Magierski teren Podzamcza fotografował także Wiktor Ziółkowski (1893-1978) - malarz, poeta, dziennikarz, człowiek o wszechstronnych zainteresowaniach artystycznych, który pozostawił po sobie kolekcję zdjęć wykonanych w latach 30. XX wieku, przedstawiających motywy staromiejskie, a przede

13 A. Tyszczyk, Poemat o mieście Lublinie i jego fotografie, „Na Przykład” 1999, nr 11/12 (listopad/ grudzień), s. 13-16; K. Dworniczak, Józef Czechowicz (1903-1939), „Scriptores”: Poza kadrem. Fotografia w Lublinie w latach 1839-1939, 2019, nr 48, s. 108-115; M. Fedorowicz, A. Kiszka, M. Skrzypek, J. Zętar, Czechowicz jako fotograf, „Scriptores”, 32, t. 3, s. 84-93.

${ }^{14}$ K. Jarzembowski, Magierski Stanisław Jacek, [w:] Polski słownik biograficzny, t. 19, Wrocław 1974, s. 171-173; K. Dworniczak, Stanisław Jacek Magierski (1904-1957), „Scriptores”: Poza kadrem. Fotografia w Lublinie w latach 1839-1939, 2019, nr 48, s. 182-190. 
wszystkim dzielnicę żydowską: dom usytuowany na rogu ulic Krawieckiej i Mostowej, widok na Podzamcze i ulicę Krawiecką, kaszarnię na rogu ulicy Ruskiej i Nadstawnej, ulicę Podzamcze, widok ogólny ze Wzgórza Czwartek ${ }^{15}$. Oryginały fotografii znajdują się w Muzeum Historii Miasta Lublina oraz w Wojewódzkiej Bibliotece Publicznej im. Hieronima Łopacińskiego, skąd pozyskiwał materiał Ośrodek „Brama Grodzka - Teatr NN”. Dwanaście skanów jest dostępnych online w Bibliotece Multimedialnej Teatru NN.

Pisząc o ikonografii lubelskiej dzielnicy żydowskiej, nie można zapomnieć o Edwardzie Hartwigu (1909-2003), jednym z najbardziej utalentowanych polskich fotografów. Edward Hartwig do zakończenia II wojny światowej mieszkał w Lublinie i prowadził przejęty po ojcu fotografie - Ludwiku Hartwigu (1883-1975) - zakład fotograficzny, gdzie oprócz portretowania realizował własne poszukiwania twórcze. Z lubelskich krajobrazów miejskich upodobał sobie szczególnie okolice Starego Miasta. Jednak za namową Wiktora Ziółkowskiego zainteresował się dzielnicą żydowską, którą z czasem zaczął traktować jako „kopalnię fotograficznych tematów”" Niestety większość zdjęć Podzamcza nie przetrwała okresu II wojny światowej. Od 2004 roku decyzją córki fotografa - Ewy Hartwig-Fijałkowskiej - w zbiorach Pracowni Ikonografii Ośrodka przechowywane są negatywy, stykówki oraz odbitki zdjęć z okresu „lubelskiego” Edwarda Hartwiga ${ }^{17}$. Pośród 3337 skanów jest kilka ujęć dzielnicy żydowskiej. Fragment spuścizny artysty jest udostępniony online w Bibliotece Multimedialnej oraz na stronie projektu „Lublin. Opowieść o mieście” (http://teatrnn.pl/opowiesci/lublin-opowiesc-o-miescie/).

Z kolei Stanisław Pastusiak - fotograf-amator, członek Lubelskiego Towarzystwa Fotograficznego i Polskiego Towarzystwa Turystyczno-Krajoznawczego, był autorem zdjęć Lublina wykonanych w 1938 roku. Są to głównie fotografie z terenu dzielnicy żydowskiej: ulica Podwale, Zamkowa, Szeroka, Basztowa, Brama Grodzka ${ }^{18}$.Zdjęcia charakteryzują się bardzo dobrą jakością techniczną, natomiast z punktu widzenia formy - szerokim planem, dzięki czemu na fotografiach Pastusiaka widocznych jest wiele szczegółów architektury i ich kontekst. Czternaście fotografii będących dokumentem, a jednocześnie próbą ujęcia codziennego życia mieszkańców Podzamcza

${ }_{15}$ K. Dworniczak, Wiktor Ziółkowski (1893-1978), „Scriptores”: Poza kadrem. Fotografia w Lublinie w latach 1839-1939, 2019, nr 48, s. 278-286.

${ }^{16}$ Cytat $\mathrm{z}$ wypowiedzi Edwarda Hartwiga zarejestrowanej na potrzeby Pracowni Historii Mówionej Ośrodka „Brama Grodzka - Teatr NN”.

17 J. Zętar, Edward Hartwig (1909-2003), „Scriptores”: Poza kadrem. Fotografia w Lublinie w latach 1839-1939, 2019, nr 48, s. 139-145; J. Zętar, Opowieść o mieście - lubelskie archiwum Edwarda Hartwiga, „Scriptores”: Poza kadrem. Fotografia w Lublinie w latach 1839-1939, 2019, nr 48, s. $470-489$.

18 K. Dworniczak, Stanisław Pastusiak, „Scriptores”: Poza kadrem. Fotografia w Lublinie w latach 1839-1939, 2019, nr 48, s. 204-207. 
udostępnionych w Bibliotece Multimedialnej Teatru NN zostało pozyskanych od syna artysty - Grzegorza Pastusiaka.

Fotografie dzielnicy żydowskiej wykonywali nie tylko fotografowie biograficznie związani z Lublinem. Okolice Zamku są motywem, który pojawia się w twórczości artystów, którzy w Lublinie byli „przejazdem”, na czas realizacji zamówień lub podczas podróży artystycznych. Wiele zabytków Lublina udokumentował Jan Bułhak (1876-1950) - praktyk i teoretyk fotografii, twórca kilkunastu tysięcy zdjęć o wysokiej wartości artystycznej i dokumentalnej. Przedstawienia charakteryzujące się standardowością ujęć były głównie wykorzystywane w produkcji pocztówek. Lubelska seria wydana w 1924 roku zawiera 25 kart pocztowych ${ }^{19}$. Na Podzamczu Bułhak wykonał jedno z najbardziej znanych ujęć ulicy Zamkowej, a także zdjęcie ulicy Szerokiej, widok ogólny na miasto żydowskie od strony starego cmentarza żydowskiego, Bramę Grodzką i Bramę Zasraną. Pocztówki wykorzystujące fotografie Jana Bułhaka w kolekcji Pracowni Fotografii pochodzą ze zbiorów Zbigniewa Lemiecha. Wszystkie są dostępne w Bibliotece Multimedialnej Teatru NN.

Lublin dokumentował również warszawski fotograf Henryk Poddębski (18901945). Wiele z jego dzieł wykonanych w Lublinie, prawdopodobnie w 1931 roku, weszło do kanonu ikonografii miasta. Zdjęcia Starego Miasta, Krakowskiego Przedmieścia, widok na Zamek i Podzamcze z placu po Farze, panorama z Czwartku, ulica Zamkowa i Zasrana Brama oraz jej okolice były prezentowane na indywidualnej wystawie zorganizowanej w 1938 roku w Lublinie ${ }^{20}$. Fotografie były publikowane jako pocztówki oraz jako materiał ilustracyjny przewodnika Stefana Wojciechowskiego Lublin wydanego w 1935 roku. Trzydzieści cyfrowych kopii zdjęć dostępnych online w Bibliotece Multimedialnej Teatru NN zostało wykonanych z materiałów znajdujących się w archiwum Lubelskiego Wojewódzkiego Konserwatora Zabytków.

Istnieje również kolekcja fotografii Lublina i regionu autorstwa Altera Kacyzne (1885-1941) - poety, pisarza i dramaturga tworzącego w języku jidysz, którego spuścizna jest przechowywana w nowojorskim YIVO Institute for Jewish Research. Zdjęcia z Lublina zostały wykonane w 1924 roku $^{21}$. Kacyzne sfotografował domy przy ulicy Mostowej i Krawieckiej, ale dużą część jego dorobku stanowią portrety

19 H. Dereczyński, Wstęp, [w:] J. Bułhak, Fotografia ojczysta, Wrocław 1951, s. 5-9; K. Dworniczak, Jan Buthak (1876-1950), „Scriptores”: Poza kadrem. Fotografia w Lublinie w latach 1839-1939, 2019, nr 48, s. 78-86.

${ }^{20}$ K. Dworniczak, Henryk Poddębski (1890-1945), „Scriptores”: Poza kadrem. Fotografia w Lublinie w latach 1839-1939, 2019, nr 48, s. 210-216.

${ }^{21}$ M. Web, Polyn. Jewish Life in the Old Country. Alter Kacyzne, New York 1999; K. Dworniczak, Alter Kacyzne (1885-1941), „Scriptores”: Poza kadrem. Fotografia w Lublinie w latach 1839-1939, 2019, nr 48, s. 153-157. 
wykonane w synagogach Maharszala i Saula Wahla, chederach oraz wizerunki osób pracujących w warsztatach rzemieślniczych lub przebywających na ulicy.

Warto przywołać również zdjęcia Romana Vishniaca (1897-1990) - biologa i anatoma, który w połowie lat 30. XX wieku podróżował po Polsce, Czechach i Węgrzech. Dotychczas znanych jest kilka kadrów wykonanych w latach 1935-1938 przedstawiających przedwojenny Lublin: tzw. „Psia górka” tuż za Bramą Grodzką, nagrobki na cmentarzu żydowskim przy ulicy Siennej, rzeka Czechówka, wizerunek nosiwody biegnącego ulicą Szeroką ${ }^{22}$.

Fotografie Kacyzne i Vishniaca są ważnym dokumentem historycznym tradycji i życia społeczności żydowskiej przed Zagładą. Obaj fotografują dobrze znany im świat, ale są „przybyszami” w tej części Europy, stąd interesują ich przede wszystkim przejawy i szczegóły życia, mniej wygląd i topografia miasta. Stosunkowo mało wiemy o fotografach żydowskich żyjących i pracujących w Lublinie do okresu II wojny światowej. Skąpa ilość materiałów archiwalnych uniemożliwia rekonstrukcję ich biografii. Ponadto ich dorobek, jak w przypadku członków Lubelskiego Towarzystwa Fotograficznego - Szaji Mameta (1900 - ok. 1942) czy Mieczysława Rotblita (? - lata 40. XX wieku), bezpowrotnie zaginął w czasie wojny. Nieco więcej wiemy o Uriaszu Szeftelu (1874 - lata 40. XX wieku) i Chillu Warmanie (około 1870 po 1916) prowadzących w Lublinie zakłady fotograficzne, w których wykonywali głównie zdjęcia portretowe. Tego rodzaju działalność prowadził również Eliasz Funk (1886 - około 1942), który oprócz portretów przyjmował zlecenia mające na celu dokumentację życia społecznego mieszkańców Lublina. W zasobach Ghetto Fighters' House zachowało się kilka zdjęć członków organizacji He-Chaluc ha-Cair wykonanych w 1933 roku w Lublinie. Ich cyfrowe kopie znajdują się w zasobach Ośrodka „Brama Grodzka - Teatr NN”23.

Praktycznie nic nie wiadomo o biografii Abrama Zylberberga, który pozostawił po sobie niezwykłą kolekcję fotografii odnalezioną w 2010 roku w Lublinie. Składa się ona z ponad 2700 szklanych negatywów przedstawiających portrety ludzi - pojedynczych osób i grup, fotografowanych w pomieszczeniach bądź w pejzażu trudnym do identyfikacji. Niektóre dokumentują wydarzenia towarzyskie i ważne wydarzenia z historii rodzin. W kolekcji znajduje się również dokumentacja ważnego wydarzenia z historii miasta - otwarcia Jesziwy, które miało miejsce w 1930 roku, oraz fotografie nagrobków z nowego cmentarza żydowskiego przy dzisiejszej ulicy

${ }^{22}$ K. Dworniczak, Roman Vishniac (1887-1990), „Scriptores”: Poza kadrem. Fotografia w Lublinie w latach 1839-1939, 2019, nr 48, s. 258-266.

${ }^{23}$ Więcej o żydowskich fotografach działających w Lublinie: „Scriptores”: Poza kadrem. Fotografia w Lublinie w latach 1839-1939, 2019, nr 48, s. 258-266. 
Walecznych. Zdjęcia prawdopodobnie zostały wykonane pomiędzy 1914 a 1939 rokiem. Kolekcja jest w całości udostępniona online ${ }^{24}$.

W zbiorach Pracowni Ikonografii znajduje się też kilka panoram przedstawiających dzielnicę żydowską od strony południowo-wschodniej i wschodniej, wykonywanych głównie w latach 30. XX wieku. Szczególne znaczenie dla poznawania topografii tej części miasta ma panorama lotnicza wykonana około 1935 roku przez nieznanego autora, której negatyw znajduje się w zbiorach Instytutu Sztuki PAN. Zdjęcie dzięki bardzo dobrej jakości prezentuje wiele szczegółów topograficznych i architektonicznych.

Na stronach Biblioteki Multimedialnej Teatru NN można również znaleźć dokumentacje wykonywane na zlecenie Magistratu Miasta Lublina w latach 30. XX wieku. Materiały znajdują się w albumach dokumentujących roboty publiczne finansowane z Funduszu Pracy podejmowane w mieście od 1937 do 1940 roku. Na zdjęciach utrwalono między innymi prace na obszarze Podzamcza - przesklepianie rzeki Czechówki oraz prace porządkowe po zakończeniu robót budowlanych, które były prowadzone od 1939 do 1940 roku. Obecnie oryginalne albumy z dokumentacją znajdują się w zasobach Archiwum Państwowego w Lublinie.

Źródłem materiałów do budowania zasobu fotograficznego Ośrodka „Brama Grodzka - Teatr NN" są też kolekcje prywatne. Dziś wiele z nich trafia do Bramy Grodzkiej dzięki działalności Pracowni Historii Mówionej, przy okazji nagrywania relacji świadków historii. W zbiorach prywatnych znajdują się przede wszystkim materiały związane $\mathrm{z}$ indywidualnymi historiami rodzinnymi, dla których tłem jest krajobraz Lublina. Przykładem takiej kolekcji są przekazane przez Netę Żytomirską-Avidar dokumenty związane z członkami jej rodziny do II wojny światowej mieszkającymi w Lublinie. Głównym bohaterem tej opowieści jest Henio Żytomirski, który w wieku 7 lat zginął w Zagładzie. Oprócz dokumentów pozwalających na rekonstrukcję życia chłopca $\mathrm{w}$ albumie zachowały się fotografie wykonywane na ulicach Lublina przez ulicznych fotografów - lejkarzy. Podobne zdjęcia znajdujące się w wielu prywatnych kolekcjach umożliwiają poznanie szczegółów codziennego życia i świątecznych zwyczajów przedwojennego Lublina.

Kres świata ze zdjęć Kiełszni, Magierskiego, Pastusiaka, Vishniaka i Zylberberga nastąpił podczas Zagłady. Jednak obszar Podzamcza w czasie II wojny światowej był nadal dokumentowany za pomocą fotografii. Fotografie przedstawiające dzielnicę

${ }^{24}$ K. Janus, Fotograf z poddasza. Zbiór szklanych negatywów odnalezionych $w$ kamienicy Rynek 4 w Lublinie (próba syntezy ustaleń), „Konteksty. Polska Sztuka Ludowa”: Misterium Bramy. Antropologia Pamięci, 2017, R. LXXI, nr 3 (318), s. 181-189; J. Zętar, Lustro z pamięcią. Kolekcja szklanych negatywów z Lublina, [w:] Sztuka Lublina od średniowiecza do współczesności. Studia i szkice, red. L. Lameński, E. Letkiewicz, P. Majewski, J. Żywicki, Lublin 2019, s. 413-427. 
żydowską powstawały w tym czasie głównie w celach prywatnych i propagandowych. Z tego okresu pochodzą znajdujące się w zbiorach Pracowni Ikonografii i udostępnione online dwie kolekcje. Są to: kolekcja siedemdziesięciu kolorowych fotografii Maxa Kirnbergera wykonana w 1940 roku, pochodząca z zasobów Deutsches Historisches Museum w Berlinie, a także prywatna kolekcja stu trzydziestu dwóch zdjęć z okresu okupacji pochodząca ze zbiorów Marka Gromaszka. W zasobach znajdują się także inne pojedyncze materiały pochodzące z kolekcji prywatnych, między innymi seria pocztówek Lublina z 1942 roku pochodząca ze zbiorów rodziny Turżańskich. Fotografie z okresu wojny dostarczają nam wielu szczegółów z topografii miasta, dzięki którym wiedza o Podzamczu staje się pełniejsza. Wykonywane przez żołnierzy niemieckich zdjęcia głównie do prywatnych albumów, przedstawiają praktycznie wszystkie miejsca wchodzące w skład obszaru Podzamcza. Powstawały przez cały okres prowadzenia działań wojennych, dlatego możemy na ich podstawie analizować między innymi życie w getcie, ale także stopniowe wyburzanie zabudowy Podzamcza po zakończeniu eksterminacji ludności żydowskiej.

$\mathrm{Na}$ obszarze Podzamcza fotografowano przede wszystkim miejsca, ludzi, a w mniejszym zakresie wydarzenia. Do najpopularniejszych miejsc należały Brama Grodzka (fotografowana przede wszystkim od strony ulicy Grodzkiej, rzadziej od strony dzielnicy żydowskiej), tzw. „Psia górka”, czyli miejsce bezpośrednio za Bramą Grodzką znajdujące się już na terenie dzielnicy żydowskiej, początkowy fragment ulicy Zamkowej, początkowy fragment ulicy Szerokiej, fragmenty ulic Podwale, Krawieckiej i Podzamcza. Bardzo popularnym motywem była tzw. Brama Zasrana. Od początków fotografowania Podzamcza powstawały widoki ogólne, w szczególności widoki z placu po Farze w kierunku Wzgórza Zamkowego, dzięki którym dobrze znany jest wygląd zabudowy południowo-wschodniej części tej dzielnicy. Znacznie mniej fotografii dokumentuje ulice Jateczną, Mostową, Nadstawną i Cyruliczą, a także ważne obiekty, w tym synagogi Maharszala i Saula Wahla, szpital żydowski, targ przy ulicy Lubartowskiej. Biblioteka Multimedialna Teatru NN udostępnia również portrety mieszkańców żydowskiego Lublina pochodzące przede wszystkim z kolekcji wykonanej przez Abrama Zylberberga. Niestety większość portretów autorstwa Zylberberga to zdjęcia anonimowych postaci, których prawdopodobnie nigdy nie uda się zidentyfikować. W zbiorach Biblioteki stosunkowo najmniej jest fotografii dokumentujących wydarzenia rozgrywające się na obszarze Podzamcza, ewentualnie dotyczących mieszkającej tam społeczności żydowskiej. W kolekcji znajduje się dokumentacja z uroczystości otwarcia Jeszywas Chachmej Lublin w 1930 roku, pogrzeb Mejera Szapiro w 1933 roku, dokumentacja budowy Domu im. I.L. Pereca z 1938 roku. Są to zdjęcia Abrama Zylberberga i anonimowych autorów pochodzące między innymi z zasobów Instytutu Sztuki PAN oraz zbiorów prywatnych. 


\section{Repozytorium pamięci}

Analiza zawartości zbiorów Pracowni Ikonografii Ośrodka „Brama Grodzka Teatr NN" udostępnianych za pośrednictwem Biblioteki Multimedialnej Teatru NN pozwala stwierdzić, że przez ponad dwadzieścia lat działalności Pracowni udało się zgromadzić materiał, dzięki któremu można odtwarzać topografię i historię dzielnicy żydowskiej w Lublinie. Warto przy tym podkreślić, że w Bramie Grodzkiej zbieranie materiałów wizualnych było od początku działaniem priorytetowym, uzupełnionym z czasem o zbieranie relacji świadków historii, kwerendy archiwalne i poszukiwanie informacji tekstowych dotyczących dzielnicy żydowskiej.

Lubelska dzielnica żydowska jest obecnie możliwa do obejrzenia i poznania przede wszystkim dzięki fotografiom. Pozornie beznamiętne zdjęcia Stefana Kiełszni, statyczne, pocztówkowe ujęcia Jana Bułhaka, postacie ludzi zatrzymane przez Altera Kacyzne i Abrama Zylberberga są dziś źródłem poznawania krajobrazu tej części miasta, wyglądu budowli ją tworzących, a także próbą odtworzenia klimatu i atmosfery nieistniejącego miasta. Oglądając zachowane przekazy ikonograficzne, zaczynamy sobie uświadamiać, jak wiele zmieniło się w Lublinie w ciągu niespełna stu lat oraz jak ciągle niepełna jest wiedza o miejscach znajdujących się niedawno w tej części miasta. Bernd Stiegler pisał, że: „Fotografia to przede wszystkim biblioteka: zbiór warstw świata zapisanych na papierze"25. Biblioteka tworzona przez Ośrodek „Brama Grodzka - Teatr NN” to zbiór warstw świata przypominających dziś palimpsest, ponieważ jedna z warstw tego świata dziś nie istnieje, ale bez niej niemożliwe jest utrzymanie pamięci o tym miejscu.

Zasób Biblioteki Multimedialnej Teatru NN z wyodrębnionym z niej zbiorem zdjęć jest fotograficznym kompendium wiedzy o żydowskim Lublinie. Ma on szczególne znaczenie dla ikonografii, dokumentacji, topografii, historii oraz dziedzictwa kulturowego Podzamcza i Lublina. Repozytorium jest magazynem informacji, a jednocześnie zbiorem nośników pamięci i śladów przeszłości. Jest cyfrowym albumem z wizerunkami miasta, portretami jego mieszkańców i informacjami, których nie ma w pisanych dokumentach, źródłach archiwalnych i opracowaniach historycznych, a bez których trudno sobie wyobrazić życie i Zagładę tego fragmentu miasta. Biblioteka Multimedialna Teatru NN jest biblioteką pamiątek po bliskich, sąsiadach Bramy Grodzkiej. Dzięki poznawaniu jej zawartości nie tylko poszerzamy wiedzę, ale doświadczamy nieobecnej przeszłości, która jak pisał Jacques Derrida, nas nawiedza i uświadamiamy sobie obecność pustych miejsc i nieobecnych osób. To uświadamianie sobie obecności i nieobecności ma też związek z pamię-

${ }^{25}$ B. Stiegler, Obrazy fotografii. Album metafor fotograficznych, tłum. J. Czudec, Kraków 2009, s. 32 . 
cią i jej główną powinnością, którą jest pamiętanie. Douwe Draaisma porównuje pamięć do szklanego negatywu. Pisał: „Ludzka pamięć stała się światłoczułą płytą, przystosowaną do fotografowania, zapisywania i reprodukcji wizualnych doświadczeń" ${ }^{26}$.

Przypadek Biblioteki Multimedialnej Teatru NN jest nie tylko fotograficzną pracą z pamięcią. Jest przede wszystkim pracą z biblioteką - repozytorium (cyfrowym), która również działa jak pamięć przez podobieństwo funkcji, praktyk i działań. Jest to też biblioteka w sensie metaforycznym, ponieważ biblioteka w swojej treści i formie staje się zmaterializowaną i uporządkowaną pamięcią. Dzięki bibliotekom pamięć kultury i pamięć miejsca uzyskuje fizyczne istnienie. Dodatkowo digitalizacja tworzy wizję nieograniczonej niczym biblioteki.

\section{Bibliografia}

Bałaban M., Żydowskie miasto w Lublinie, tłum. J. Doktór, Lublin 2012.

Bielecka-Hołda M., Wielka Ksiegga miasta, „Scriptores”: Poza kadrem. Fotografia w Lublinie w latach 1839-1939, 2019, $\mathrm{nr} 48$, s. 323-334.

Bomba R., Brama 2.0. Animacja kultury cyfrowej w działaniach Ośrodka „Brama GrodzkaTeatr NN”, „Konteksty. Polska Sztuka Ludowa”: Misterium Bramy. Antropologia Pamięci, 2017, R. LXXI, nr 3 (318), s. 141-148.

Chmielewski J., Zagłada żydowskiego miasta - likwidacja getta na Podzamczu, „Kwartalnik Historii Żydów" 2015, nr 4, s. 705-739.

Dereczyński H., Wstęp, [w:] J. Bułhak, Fotografia ojczysta, Wrocław 1951, s. 5-9.

Dworniczak K., Alter Kacyzne (1885-1941), „Scriptores”: Poza kadrem. Fotografia w Lublinie w latach 1839-1939, 2019, nr 48, s. 153-157.

Dworniczak K., Henryk Poddębski (1890-1945), „Scriptores”: Poza kadrem. Fotografia w Lublinie w latach 1839-1939, 2019, $\mathrm{nr}$ 48, s. 210-216.

Dworniczak K., Jan Buthak (1876-1950), „Scriptores”: Poza kadrem. Fotografia w Lublinie w latach 1839-1939, 2019, $\mathrm{nr} 48$, s. 78-86.

Dworniczak K., Józef Czechowicz (1903-1939), „Scriptores”: Poza kadrem. Fotografia w Lublinie w latach 1839-1939, 2019, $\mathrm{nr}$ 48, s. 108-115.

Dworniczak K., Roman Vishniac (1887-1990), „Scriptores”: Poza kadrem. Fotografia w Lublinie w latach 1839-1939, 2019, $\mathrm{nr} 48$, s. 258-266.

Dworniczak K., Stanisław Jacek Magierski (1904-1957), „Scriptores”: Poza kadrem. Fotografia w Lublinie w latach 1839-1939, 2019, $\mathrm{nr} 48$, s. 182-190.

Dworniczak K., Stanisław Pastusiak, „Scriptores”: Poza kadrem. Fotografia w Lublinie w latach 1839-1939, 2019, nr 48, s. 204-207.

Dworniczak K., Wiktor Ziótkowski (1893-1978), „Scriptores”: Poza kadrem. Fotografia w Lublinie w latach 1839-1939, 2019, nr 48, s. 278-286.

26 Za: B. Stiegler, op. cit., s. 162-163. 
Fedorowicz M., Fotografie Lublina do 1939 roku w zbiorach Pracowni Ikonografii Ośrodka „Brama Grodzka - Teatr NN”, „Scriptores”: Poza kadrem. Fotografia w Lublinie w latach 1839-1939, 2019, nr 48, s. 335-364.

Fedorowicz M., Kiszka A., Skrzypek M., Zętar J., Czechowicz jako fotograf, „Scriptores” 2008, nr 32, t. 3, s. 84-93.

Gawarecki H., Dawny Lublin na fotografiach Stefana Kiełszni, Lublin 1975.

Janus K., Fotograf z poddasza. Zbiór szklanych negatywów odnalezionych w kamienicy Rynek 4 w Lublinie (próba syntezy ustaleń), „Konteksty. Polska Sztuka Ludowa”: Misterium Bramy. Antropologia Pamięci, 2017, R. LXXI, nr 3 (318), s. 181-189.

Jakubowski A., Bronisz U., Łoś E., Historia Lublina w liczbach, Lublin 2017.

Jarzembowski K., Magierski Stanisław Jacek, [w:] Polski słownik biograficzny, t. 19, Wrocław 1974, s. 171-173.

Księga pamięci żydowskiego Lublina, wybór, oprac. i wstęp A. Kopciowski, Lublin 2011.

Kuwałek R., Wysok W., Lublin. Jerozolima Królestwa Polskiego, Lublin 2001.

Libionka D., Zagłada Żydów w Generalnym Gubernatorstwie, Lublin 2017.

Lipniewski J., Widokówki lubelskie - historia i znaczenie dla ikonografii miasta (1896-1939), [w:] Ikonografia dawnego Lublina, red. Z. Nestorowicz, Lublin 1999, s. 88-119.

Majuk D., Wiśniewska A., Dworniczak K., Kiełsznia Stefan (1911-1987), „Scriptores”: Poza kadrem. Fotografia $w$ Lublinie $w$ latach 1839-1939, 2019, nr 48, s. 162-173. Ulica Nowa 3. Stefan Kiesznia. Historyczne zdjęcia ulic żydowskiej dzielnicy w Lublinie, Lipsk 2011.

Odnous B., Fotograf zaginionego miasta, „Karta” 2000, nr 31, s. 10-15.

Pietrasiewicz T., Teatr Pamięci Teatru NN, Lublin 2017.

Próchniak P., Brama jako archiwum. Działania archiwizacyjne Ośrodka „Brama Grodzka - Teatr NN” w Lublinie, „Kultura i Społeczeństwo”: Społeczne w archiwach, 2019, t. 63, nr 1, s. 113-123.

Przypadek zamierzony. Dlaczego właśnie Krawiecka 41, z Tomaszem Pietrasiewiczem rozmawia Marcin Skrzypek, „Scriptores” 2003, nr 28.

Radzik T., Zagłada lubelskiego getta, Lublin 2007.

"Scriptores": Poza kadrem. Fotografia w Lublinie w latach 1839-1939, 2019, nr 48.

Stiegler B., Obrazy fotografii. Album metafor fotograficznych, tłum. J. Czudec, Kraków 2009. Teatr Pamięci Teatru NN. Flesze, red. P. Próchniak, Lublin 2018.

Tyszczyk A., Poemat o mieście Lublinie i jego fotografie, „Na Przykład” 1999, nr 11/12 (listopad/grudzień), s. 13-16.

Web M., Polyn. Jewish Life in the Old Country. Alter Kacyzne, New York 1999.

Zętar J., Edward Hartwig (1909-2003), „Scriptores”: Poza kadrem. Fotografia w Lublinie w latach 1839-1939, 2019, nr 48, s. 139-145.

Zętar J., Jak budowano plac Zamkowy..., „Gazeta Wyborcza. Magazyn Lubelski” 18.08.2017, s. $6-7$.

Zętar J., Lustro z pamięcią. Kolekcja szklanych negatywów z Lublina, [w:] Sztuka Lublina od średniowiecza do współczesności. Studia i szkice, red. L. Lameński, E. Letkiewicz, P. Majewski, J. Żywicki, Lublin 2019, s. 413-427.

Zętar J., Opowieść o mieście - lubelskie archiwum Edwarda Hartwiga, „Scriptores”: Poza kadrem. Fotografia w Lublinie w latach 1839-1939, 2019, nr 48, s. 470-489. 
Pobrane z czasopisma Folia Bibliologica http:/foliabibliologica.umcs.pl

Data: 26/04/2023 14:15:01

Zętar J., Szeroka - opowieść o ulicy, której nie ma, „Gazeta Wyborcza. Magazyn Lubelski” 25.08.2017, s. 8-9.

Żydzi lubelscy. Materiały z sesji poświęconej Żydom lubelskim, red. W. Hawryluk, G. Linkowski, Lublin 1996.

Żydzi w Lublinie. Materiały do dziejów społeczności żydowskiej Lublina, red. T. Radzik, Lublin 1995.

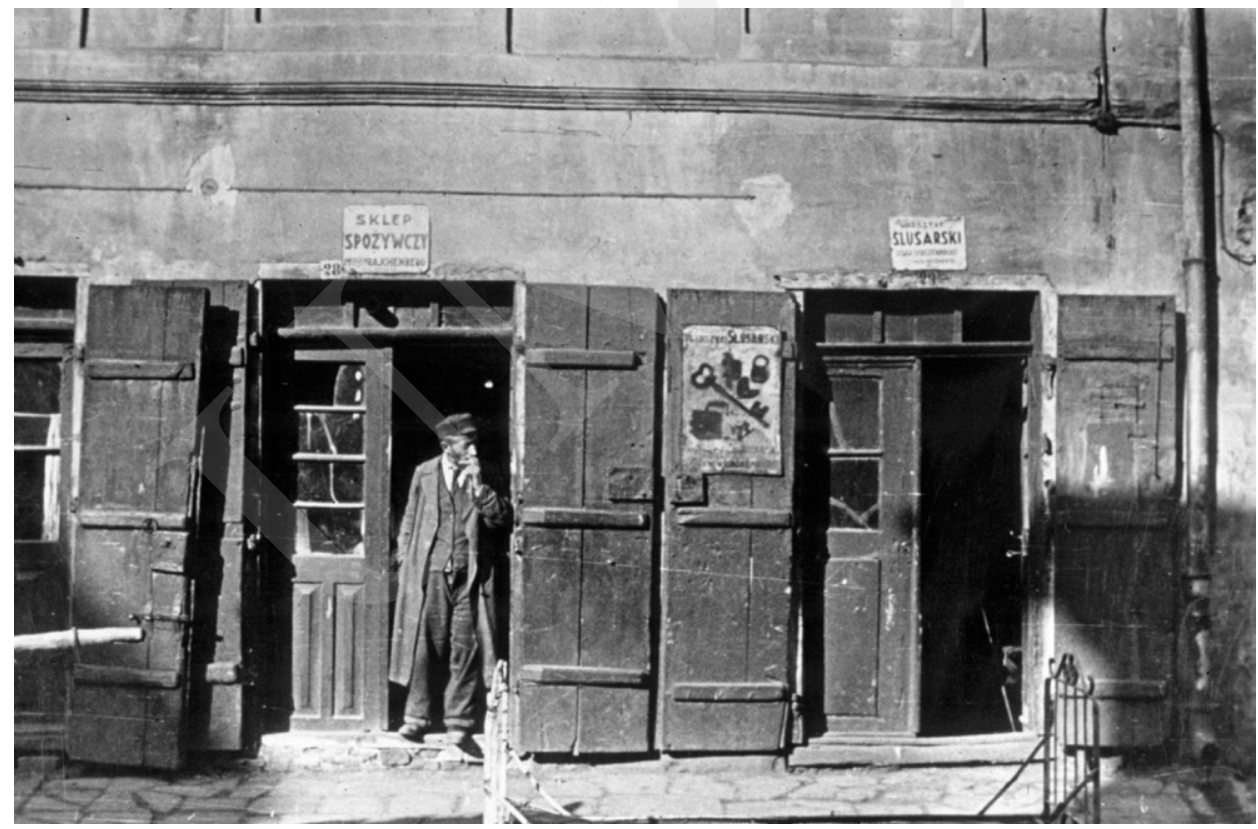

Fot. 1. Ulica Szeroka 12, fot. Stefan Kiełsznia, 1934 rok, zbiory Jerzego Kiełszni/ Pracownia Ikonografii Ośrodka „Brama Grodzka - Teatr NN”. 
Pobrane z czasopisma Folia Bibliologica http:/foliabibliologica.umcs.pl

Data: 26/04/2023 14:15:01

Wielka Księga Miasta. Fotografie lubelskiej dzielnicy żydowskiej...

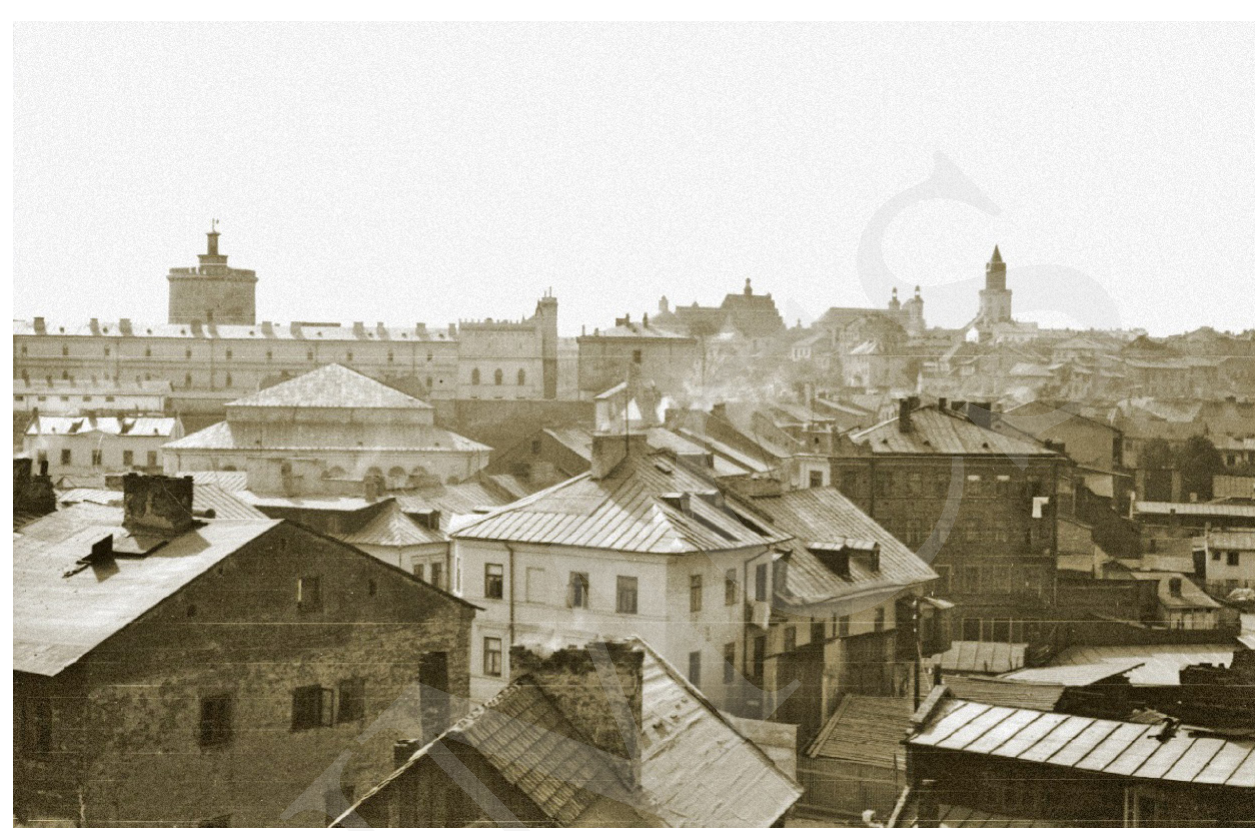

Fot. 2. Panorama dzielnicy żydowskiej ze Wzgórza Czwartek, fot. Stanisław Magierski, lata 30. XX wieku, zbiory rodziny Magierskich.

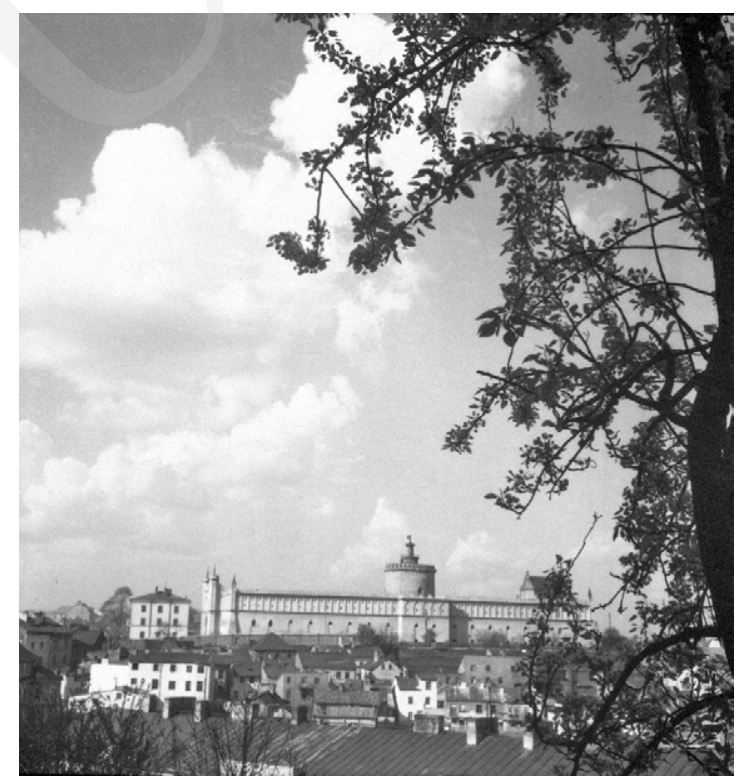

Fot. 3. Panorama Podzamcza z placu po Farze, fot. Edward Hartwig, lata 30. XX wieku, zbiory Ewy Hartwig-Fijałkowskiej/Pracownia Ikonografii Ośrodka „Brama Grodzka - Teatr NN”. 
Pobrane z czasopisma Folia Bibliologica http:/foliabibliologica.umcs.pl

Data: 26/04/2023 14:15:01

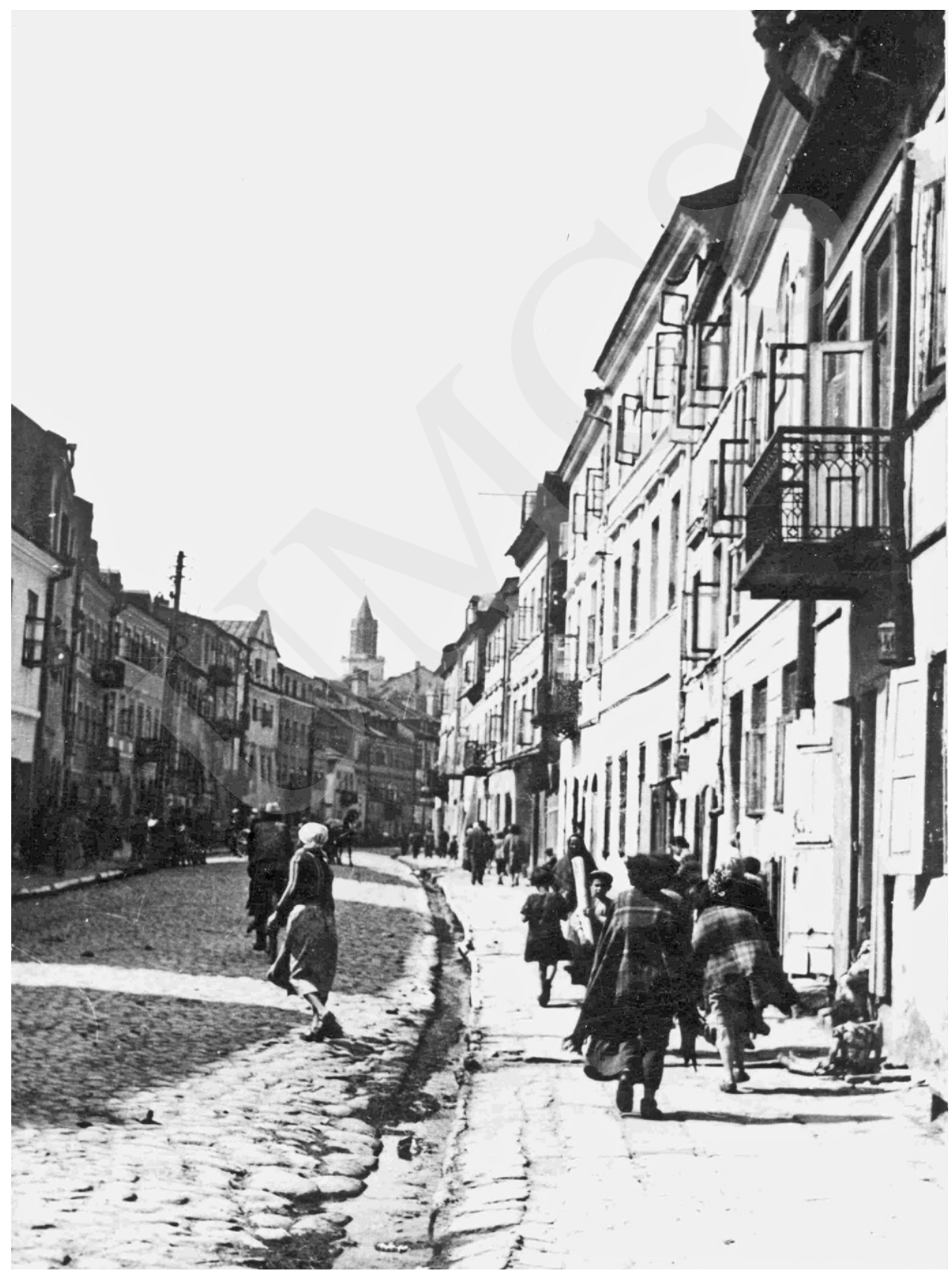

Fot. 4. Ulica Szeroka, fot. Stanisław Pastusiak, 1938 rok, zbiory Grzegorza Pastusiaka. 


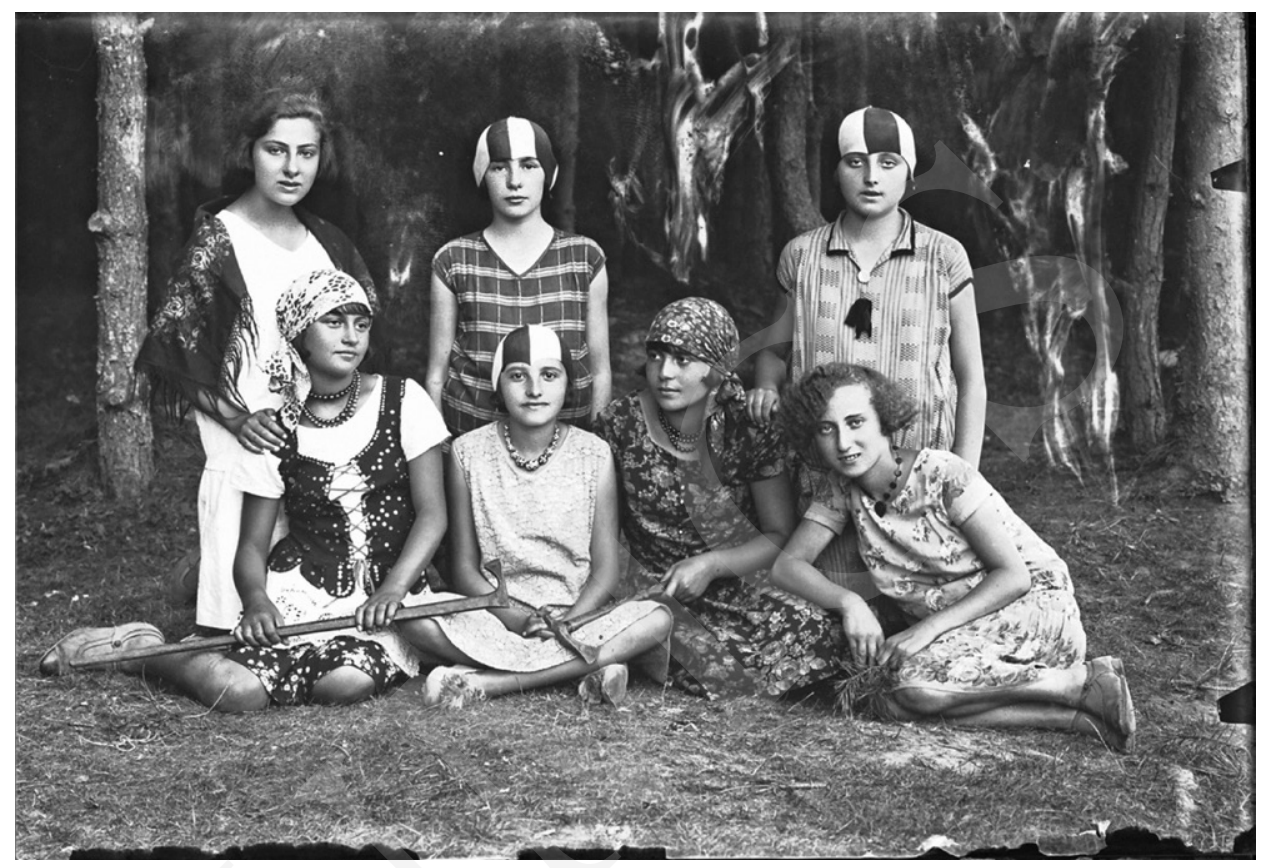

Fot. 5. Zdjęcie zbiorowe dziewcząt podczas wakacji w Nowodworze, pierwsza z lewej: Róża Fiszman-Sznajdman, fot. Abram Zylberberg, koniec lat 30. XX wieku, kolekcja szklanych negatywów z Rynku 4 w depozycie Ośrodka „Brama Grodzka - Teatr NN”. 